\title{
JOURNALISTIC EDUCATION IN THE CHUVASH REPUBLIC
}

\author{
Anatoliy P. Danilov ${ }^{1}$, Andrey A. Danilov ${ }^{2}$, Margarita G. Danilova ${ }^{3}$ \\ Valeriy P. Komissarov ${ }^{4}$, Amin M. Eshkerat ${ }^{5}$, Elvira V. Chueva ${ }^{6^{*}}$ \\ ${ }^{1}$ Head of Chair, Chuvash State University, RUSSIA, anatoliy.p.danilov@gmail.com \\ ${ }^{2}$ Prof. Dr., Chuvash State University, RUSSIA, danilov.andrey@mail.ru \\ ${ }^{3}$ Assoc. Prof., Chuvash State University, RUSSIA, danilova1956@gmail.com \\ ${ }^{4}$ Assoc. Prof., Chuvash State University, RUSSIA, valerijkomissarov134@gmail.com \\ ${ }^{5}$ Assoc. Prof., Chuvash State University, RUSSIA, eshkeratamin@gmail.com \\ ${ }^{6}$ Assoc. Prof., Chuvash State University, RUSSIA, 570065@mail.ru \\ ${ }^{*}$ Corresponding Author
}

\begin{abstract}
The purpose of the study is to analyze the history of the formation and development of training journalistic personnel at the Chuvash State University named after I.N. Ulyanov. The activity of the branch of the Department of Journalism at the Union of Journalists of Chuvashia, the work of students in creative studios under the guidance of leading employees of radio channels and television studios, chief editors of republican printed publications are noted. The work of the small faculty of journalism, created with the aim of organizing vocational guidance work, governing bodies of the faculty of journalism, student scientific society, editorial and publishing center, is investigated, the level of the material and technical base of the faculty is assessed. The structure of the curriculum at various historical stages, the provision of educational literature, access to information databases are considered. It is concluded that the training of journalistic personnel at the Chuvash State University named after I.N. Ulyanov went through three stages: training journalists through specialization (1967-1993); five-year professional training (1994-2013); a stage of multilevel training for journalists (since 2014). Today, there are all conditions allowing the students to practically realize their creative potential. Along with studying theoretical issues in lecture and practical classes, they learn the basics of practical journalism. Young people are introduced to the conditions and factors of mass media formation and functioning, methods and techniques of typological analysis, principles of organizational and functional structure of the editorial office. Students have an opportunity to prove themselves in a certain kind of journalistic specialization and profession: by official and functional features, by subject and genre orientation, by mass media, by audience orientation of periodicals. The experience of many years of work on training the journalistic staff shows it is in great demand at every stage of historical development. Further improvement of the system of educating creative workers of mass media editorial offices, taking into account market conditions development and new information technologies expansion - this is the major goal of the staff of the Department of Journalism of the I.N. Ulyanov Chuvash State University.
\end{abstract}

Keywords: history, journalistic education, science, Chuvash State University named after I.N. Ulyanov, equipment, personnel.

\section{INTRODUCTION}

All the text must be in one column and Arial font, 10 point, normal, justified alignment, including figures and tables, with single-spaced interline spacing.

This template will assist you in formatting your paper. Please, copy it on your computer and insert the text keeping the format and styles indicated. The various components of your paper (title, abstract, keywords, 
sections, text, etc.) are already defined on the style sheet, as illustrated by the portions given in this document.

\section{METHODOLOGY}

The methodological basis of this publication is: the principles of historicism, the systematic nature of the study, which allow to reveal the general features of historical processes. The study of the history of journalistic education in Chuvashia, the general tendencies of its formation, development, the relationship of journalism and socio-political, cultural changes in society were carried out on the basis of the historicaltypological method. An interdisciplinary approach at the intersection of journalism and historical science allowed a deeper and more objective study of the events and phenomena in question.

\section{RESULTS}

Issues of training journalistic personnel at the Chuvash State University named after I.N. Ulyanov were discussed almost from the first days of its opening in September 1967. In November 1967, on the recommendation of the board of the Union of Journalists of the Chuvash Autonomous Soviet Socialist Republic, the practical journalist I.Ya. Tenyushev was invited to the department of the Chuvash language and literature to teach journalistic disciplines. This is how the training of Chuvash-speaking journalistic personnel at the university began through specialization. Having started working on an hourly basis, he subsequently worked his way up from an assistant and senior teacher to an associate professor and professor.

Member of the Great Patriotic War of 1941-1945. I. Ya. Tenyushev graduated from the journalistic department of the Higher Party School under the Central Committee of the CPSU in 1964. His Ph.D. thesis «Literary and journalistic activities of the Chuvash educator I.Ya. Yakovlev» he defended at the Lviv State University named after Ivan Franko. Later he worked in the positions of executive secretary of the district newspaper, editor of the district newspaper, Komsomol-youth newspaper of Chuvashia, head of the editorial department of the republican newspaper «Kommunism yalave», head of the press, television and radio broadcasting sector of the Chuvash regional committee of the CPSU. It was not easy for him to work on training specialists of a new profile, since there were no programs or textbooks on the disciplines of national journalism at that time. He had to work on the preparation of lecture notes, exercise cycles for the disciplines of specialization. Step by step he developed courses of lectures on the history of Chuvash journalism, the basics of journalism, the translation of newspaper materials from Russian into the Chuvash language, literary editing and the skills of a journalist.

There was a period when an attempt was made to nullify specialization by transferring to optional basis. Only the intervention of the bureau of the regional committee of the CPSU helped to preserve the specialization of journalistic personnel at the university in its original status.

After retirement in 1984 before returning to the university in 1998 I.Ya.Tenyushev worked as an editor and senior editor at the Chuvash book publishing house. At the same time he went into business - he organized a production, publishing and trade enterprise «Bulgar», which published 21 books, many other printed materials.

Together with the students, he prepared the book «Dreams and Frustrations of Entrepreneurs». A book about the agrofirm named after V.I. Lenin in the Batyrevsky district. His main scientific works during the years of work at the university I.Ya. Tenyushev devoted to the history and theory of Chuvash journalism: to the analysis of the journalistic activities of figures of Chuvash culture. These include «The role of the wall press in the organization and education of the children's collective» (1959), «Radio is an important form of party propaganda» (1960), «Literary and journalistic activities of the Chuvash educator I. Ya. Yakovlev»(1980), «Mass raids of workers and rural correspondents in Chuvashia» (1983), «The weapon of a publicist» (about the journalistic activities of the Chuvash national poet Y. G. Ukhsai) (1984), "The first Chuvash publicists» (1987), «I. Ya. Yakovlev-Publicist» (1980), «Formation and Development of Chuvash Publicism and Journalism» (1999). (co-authored with A.P. Danilov), "The initial stages of the Chuvash journalism and journalism» (2004) (in the Chuvash language, co-authored with A.P. Danilov).

With the expansion of the training of journalistic personnel on an hourly basis, the editor of the newspaper «Pioner sassi» K.S. Sergeev was invited to teach practical lessons, and the executive secretary of the newspaper «Kommunism yalave» V.P. Petrova. After some time, associate professor K.K. Petrova from the University of Kazan was invited. During the first 18 years at the university 150 specialists were trained and sent to work in their profession. (Danilov, A.P., 2017). 
In 1984, in connection with the retirement of the of associate professor I.Ya. Tenyusheva, associate professor K.K. Petrov., a famous writer, researcher of the early stage of development of Chuvash journalism, who was transferred from the Faculty of Journalism of Kazan State University, began teaching journalism.

At the Chuvash State University, specialty 021400 - «Journalism» was opened in 1994. On May 15, 1995, the department of journalism was opened (headed by A.P. Danilov). Well-known journalists and researchers G.V. Krasnov, K.K. Petrov, G.N. Zheltukhin, L.I. Ilyin, V.N. Nikolaev, I.I. Semenov, V.A. Zhebit, V.P. Komissarov, I.M. Grigoriev, A.S. Abramov, A.V. Tarasov, V.A. Ivanova, M.I. Ivanov, I. Ya. Tenushev, N.I. Zavgorodnyaya, A.P. Leontiev, B.V. Chindykov, V.M. Savelyeva, E.A. Kanyuk, E.V. Nikitina, L.I. Filippova, S.L. Pavlov, S.A. Alexandrov, G.V. Wakku, A.A. Kirillova, L.A. Budnichenko and others worked there.

The first recruitment at the Faculty of Journalism (Dean - A.P. Danilov) began to study on September 1, 1995. Since that time, it has become possible to train journalistic personnel both for the Chuvash-speaking (including the mass media of the Chuvash diaspora) and for Russian-language periodicals.

In the early years, journalists were trained at the department of Chuvash journalism and the department of Russian journalism (full-time education). The faculty trained students not only from Chuvashia, but also from many regions of Russia: from the Republics of Bashkortostan, Komi, Mari El, Sakha (Yakutia), Tatarstan, Chukotka Autonomous Okrug, from Irkutsk, Kirov, Penza, Samara, Tyumen, Ulyanovsk regions, from cities of Vorkuta, Voronezh, Surgut, Togliatti. Students from foreign countries (Kenya, Syria, Morocco, Turkey) also studied there.

The structure of the Faculty of Journalism included 3 departments:

1) Department of Journalism;

2) Department of Electronic Mass Media and Advertising;

3) Department of literary editing and stylistics.

The opening of a branch of the journalism department at the Union of Journalists of Chuvashia in 1995 contributed to the improvement of students' practical work. The work of students in creative studios was supervised by the leading employees of radio channels and television studios, the chief editors of the republican print media.

Since 1995, a «small faculty of journalism» has been working at the faculty, created with the aim of organizing career guidance work, preparing applicants for a creative competition.

The governing body was the Academic Council of the Faculty. The Student Council also took an active part in the management of the faculty, whose members participated in educational events, student selfgovernment, the publication of student newspapers, etc.

The faculty also had a student scientific society (SSS), created to organize the scientific activities of students. To a large extent, this was facilitated by the holding of a student scientific and practical conference at the faculty, where sections on history, theory, practice of journalism worked.

An editorial and publishing center was created at the Faculty of Journalism, within the framework of which teachers, staff and students prepared student newspapers, magazines, and educational literature.

The faculty had at their disposal:

1) A computer class with modern personal computers equipped with Internet access. It held classes in disciplines related to informatics, modern computer technology, newspaper and magazine design, modern technical means of journalism;

2) A photographic laboratory with a useful area of $36 \mathrm{sq}$. $\mathrm{m}$. with various photographic equipment and cameras, where each student had the opportunity to work in their free time. Here, classes were held for a photo club, where students learned the basics of photography, classes on the technical means of a journalist and on photojournalism;

3) An editorial and publishing center, where there was a risograph, printers, computers, scanners and other equipment. Here, students published educational student newspapers, prepared books, magazines;

4) Radio center TU-100;

5) Educational television. Classes in television journalism and work in creative studios were held here.

Educational television was founded in 1977 and was a powerful university structure in the 1980s.: regular 
cable broadcasting covered all educational buildings, broadcasting of original news programs took place, students were taught with the use of special television courses. With the advent of widespread access to computers in the 1990s. there was a decline in the interest of the university community in educational television.

Students of the Faculty of Journalism, who studied television journalism, along with classes on educational television, regularly took practice in creative studios on the "Kanal $5+», ~ " M T V$ », State Television and Radio Broadcasting Company "Chuvashia», and since 2011 - the National Radio and Television Campaign of Chuvashia. The material and technical base of various editions of radio and television, print media and the branch of the journalism department at the Union of Journalists of Chuvashia was widely used.

The structure of the curriculum for the specialty "Journalism» provided for the study of the following disciplines:

1) General humanitarian and socio-economic;

2) General mathematical and natural sciences;

3) General professional;

4) Special.

Each of the presented cycles consisted of disciplines of the federal component, disciplines of the nationalregional (university) component, disciplines of the student's choice. Disciplines of the regional component («History of the Chuvash people», «Material and spiritual culture of Chuvashia»), at the choice of the student («World religions», «Modern international relations», «Foreign languages») substantively complemented the disciplines of the federal cycle.

The block of special disciplines included all disciplines established by the state educational standard, and optional disciplines - «Journalistic skills» (work in creative studios of choice: in the editorial office of a newspaper, magazine, radio, television, in a publishing house, etc.). There were additional types of training military and medical (at the student's choice), an optional discipline «Office work».

The provision of textbooks and teaching aids in different disciplines at the faculty was various. Each student had access to library funds of fiction, educational and scientific literature, periodicals. In addition, students of the Faculty of Journalism could use the rich collection of literature of the National Library named after M. Gorky and the Book Chamber of the Chuvash Republic. The library of the Chuvash State University annually signed newspapers and magazines published in the Chuvash Republic and central publications, including professional ones: "Vestnik of the Moscow University. "Journalism»», "Journalist», "Fourth Estate», «Reading Russia», "Sreda». The library also had periodicals on various specializations: librarianship, pedagogy (Pedagogy, Education of Schoolchildren, Public Education, etc.), advertising, photojournalism, literary criticism, and publishing.

Students had access to various information databases, network sources of information. For this, the educational building had an Internet center, where each student could work at a convenient time for him. In 2000 , the Internet was installed in the computer class at the faculty.

Cognitive activities of students were intensified by meetings, round tables, press conferences with artists, politicians, prominent journalists, writers, etc. In September 2002, at a meeting with students of the Faculty of Journalism, one of the authors of the law "On the Press and Other Mass Media Information "Doctor of Law, Professor, Hero of Russia, cosmonaut Yu.M. Baturin. Over the years, master-classes were held with students of the Faculty of Journalism by L.A. Yakubovich, V.V. Pozner, A.A. Arkhangelsky, L.A. Kokhanova and other well-known Russian journalists.

During the studies, the level of practical skills and knowledge of students was regularly monitored. At the same time, such forms of control as credits, examinations were traditionally used, between exam periods tests and attestations were carried out. Teachers began to regularly use express-polls and a test control system to check students' independent work.

Faculty students took an active part in research work. Student scientific conferences were held annually, where the following sections worked: «History of journalism», «Domestic journalism», «Journalism skills», «Actual problems of journalism», "The system of mass media of the Chuvash Republic», "Foreign journalism», «Psychological and pedagogical Fundamentals of Journalism», «Television and Radio Journalism», etc. Here students made interesting meaningful theses and messages, prepared posters, presentations, used technical means, prepared photo exhibitions, etc. The materials of the winners at the 
conference were published in student collections of scientific works. In addition, future journalists actively participated in the annual interregional conferences «Youth of the Big Volga», «Man. Citizen. Scientist».

The pride of the Faculty of Journalism is student Yanina Ptak, who in 2001 took 1st place in the competition for the best student scientific work, organized by the Ministry of Education of the Russian Federation. In the same year, the student was awarded the gold medal of the Russian Academy of Sciences and the prize for her other scientific work. From 15 to 22 April 2001, she participated in the International Scientific Congress.

The expansion of the professional range of journalism students, the improvement of practical skills and abilities is facilitated by educational-production and continuous practice, which is carried out in the editorial offices of regional and republican newspapers and magazines, radio and television, advertising agencies. The faculty had agreements with the editorial offices of the republican mass media on cooperation. In accordance with these agreements, creative studios were opened in the editorial offices of the newspapers «Khypar», «Khreschen sassi», "Ulyanovets», "Soviet Chuvashia», «Cheboksary news», «MK in Cheboksary», in the editorial offices of the magazines «Tavan Atal», "Samant», STRC "Chuvashia», "Kanal $5+»$, National Television and Radio Broadcasting Company of Chuvashia, in the editorial and publishing center, the press service and information department of the Chuvash State University. The faculty actively used the material database of editions. Work in creative studios according to the curriculum was provided for in the 2nd semester. One school day was allocated for this work in the schedule.

From the day the specialty was opened, student educational newspapers «Vesti Alma-mater», «Nonparel» were published at the faculty. Students actively participated in the process of preparing materials for newspapers and prototyping, editing and computer typesetting. In addition to newspapers, the educational and publishing center also prepared collections of scientific papers, educational and methodological manuals, magazines. In 1996-2001 newspapers were published for contract organizations and enterprises «Chuvash Energetic», "Chuvash surame», «Pattar En», all-Russian magazines «Family in Russia», «Integral Pedagogy», "Bulletin of the Associatiuon of Russian Universities», "School of Spirituality», «Izvestia RAO» and others. The students of the faculty, under the guidance of experienced teachers, actively participated in the publication of these works, performed practical tasks on the main newspaper genres, published their materials, typed on a computer, typeset, that is, they were included from the first year in everyday practical activities.

Students' practice was subdivided into educational and industrial practice. During the practice, theoretical knowledge and skills were tested in editorial offices, consolidated and improved, professional orientations were refined and developed.

While studying, many worked part-time in various media (on average 5-8 students per group). For example, a 5th year student Oksana Voznyak worked in the newspaper «MK in Cheboksary» from her second year, then became the editor-in-chief of this newspaper. A 4th year student Lina Makarova was the chief editor of the newspaper «Achapacha», and Dmitry Moiseev - «Samraksen khasache». Graduates and students of the Faculty of Journalism went on air on radio and television every day. In the final course, most graduates were determined in the choice of a place of work. Consumers of journalism specialists spoke positively about the quality of preparedness of graduates and recommended training more specialists in the press service, advertising, and public relations. Specialists were distributed not only in the Chuvash Republic, but also in other regions of the Russian Federation, countries of the near and far abroad.

The scientific work of the departments was carried out in accordance with the plan for the training of specialists in journalism and was practically aimed at increasing the efficiency of the functioning of local mass media. With the opening of a new department - the department of electronic media and advertising this direction has expanded and research has begun in the field of television and radio journalism.

Scientific contacts of the departments with the leading scientific centers of the country were constantly maintained, where the journalistic personnel were trained - Voronezh, Yekaterinburg, Kazan, Mari, Moscow, St. Petersburg state universities.

The Faculty of Journalism maintained scientific ties with the leading research centers of the Russian Federation. Agreements were signed with the Faculties of Journalism of Moscow and St. Petersburg Universities, within the framework of which issues of cooperation in the field of joint scientific research, postgraduate and doctoral studies were envisaged. Graduates-journalists, who have defended thesises: Professor of the Department of Journalism A.A. Danilov (doctoral thesis on the history of regional television in Russia), E.V. Nikitina, I. V. Varlamova, T.N. Pirozhkova, O. V. Ivanova (Danilov, A.A., 2008, p. 123).

In addition, a number of journalism students have been sent to continue their studies abroad. N. Fedotov, A. 
Astrov, E. Malyshev continued their education in Turkey. Graduate N. Myshkina studied in postgraduate studies in Turkey. A student M. Petrova finished her studies in the USA, she also studied in graduate school in Holland. In 1999, student of the Faculty of Journalism A. Mikhailov studied in Sweden. Professor of the Department of Journalism A.A. Danilov completed an internship in Sweden (2013).

In September 2002, a representative of Palestine, Eshkerat Amin Mukhamad, who graduated from the Peoples' Friendship University of Russia in Moscow with a degree in International Journalism and defended his dissertation, was hired.

In general, the faculty carried out active work on the creation of personnel, scientific and methodological potential, which would provide high-quality training of specialists. The educational process was organized in accordance with the curriculum. Various methods and forms of enhancing the cognitive activity of students, control of their knowledge were widely used. The educational and scientific process was focused on practical activities, communication with consumers of specialists. In the educational process, new information technologies were actively used (Danilov, A.A., 2006, p. 95).

The newspaper «Vesti Alma-mater», which was published from 1998 to 2003 by the faculty of journalism, became popular among the periodicals of the republic. It covered the multifaceted student life, acquainted readers with various problems of youth, brought up for discussion issues of moral education, organization of the educational process and leisure, had close contacts with the student council and the trade union committee. Due to the lack of offset printing equipment, the first issues of the newspaper were printed in Tsivilsk. The university administration decided to equip the university printing house with modern technology that allowed high-quality printing of newspaper and book products. In this regard, additional opportunities have appeared for the operational publication of both the student newspaper "Vesti Alma-mater» and the university-wide periodicals «Ulyanovets», "Chuvashia today».

The Faculty of Journalism has become a methodological center for introducing new technology into the publishing process. The curriculum included such disciplines as "Technique and technology of mass media», «Issue of an educational newspaper», «Newspaper and magazine design», "Informatics», etc. The teachers helped many editorial offices of district newspapers to switch to computer technology for preparation and production of periodicals. The result of fruitful cooperation of the university with OJSC "Chuvashenergo", the collective farm "Chuvashskaya Sorma» and Batyrev community became the newspapers «Chuvash Energetic», "Chuvash Surame», «Pattar En». For students of the «Small Faculty of Journalism» (preparatory courses) there was a newspaper «Nonparel». This active publishing activity contributed to the fact that many students collaborated professionally in the media, some of them became newspaper editors.

An example of support for students' creative endeavors was the publication of books of essays and sketches about their contemporaries "Their feat is immortal», "There is nothing dearer than native land», "The native village - Almanchikovo», collections of poems by Oksana Ivanova, Olga Afanasyeva, Elena Krylova, Yanina Ptak, Maxim Prikhodchenko, llya Kazakov.

Students actively participated in the preparation and publication of educational and scientific-methodical literature on journalism. At the same time, they did not limit themselves to publishing books by local authors; they published works by scientists from Moscow, St. Petersburg, Kazan, Voronezh, Saransk, Yoshkar-Ola, Ufa, Yakutsk and other cities.

Another important area of training journalistic personnel was the participation of students in the release of special issues of the magazines "Tavan Atal» (the magazine of the Ministry of Press and Information Policy of the Chuvash Republic), "lzvestia of Russian Academy of Education», "Family in Russia» (founders State Research Institute of family and upbringing of the Russian Academy of Education, Ministry of Labor and Social Development of the Russian Federation), «Integral Pedagogy» (co-founders - All-Russian Institute of Integral Pedagogy and Chuvash State University), "School of Spirituality» (founder - All-Russian Institute of Integral Pedagogy), " «Bulletin of the Association of Russian Universities». Future journalists participated in all cycles of the technological process of issuing these publications. For the preparation of the journal « Bulletin of the Association of Russian Universities» students of the Faculty of Journalism received a written gratitude from the rector of the Moscow State University of Geodesy and Cartography, the USSR pilot-cosmonaut, the president of the Association of Russian Universities, Doctor of Technical Sciences, Professor V.P. Savinykh (Danilov, A.P., 2011, p. 6).

In 2013, the Faculty of Journalism joined the Faculty of Russian and Chuvash Philology and Journalism. In the new conditions of the transition to a multi-level system of training journalistic personnel and changes in federal state educational standards, it became necessary to revise the curricula and optimize the staff 
structure. From 2013 to 2015 , admission to the training direction 42.03 .02 «Journalism» was carried out only on a contract basis. The system of bilingual training of journalists created over the years was preserved, and thanks to the efforts of the administration, budget places appeared. In 2016, there were 10 budget places, in 2017 - 12. In 2016, 3 academic groups were admitted together with contractors.

Today, there are all conditions for students to practically realize their creative potential. Along with the study of theoretical issues in lectures and practical classes, they comprehend the basics of practical journalism. Young people get acquainted with the conditions and factors of the formation and functioning of the media, methods and techniques of typological analysis, the principles of the structure of the organizational, functional and job structure of the editorial office. Students have the opportunity to test themselves in one form or another of journalistic specialization and profiling: by job and functional characteristics, by thematic and genre focus, by the media, by the audience focus of a periodical.

In the process of educational and publishing activities, a model of the journalist's personality is developed, his civil, moral, professional, psychological characteristics are manifested. The student receives the skills of self-education, goes through all the main stages in the development of professionalism: education, skill, mastery. By creating a journalistic work, participating in the preparation and publication of a periodical, the future specialist gets acquainted with the specifics of the stage of cognition of reality, depending on cognitive activity, forms a specific idea, implements it, and edits the material.

The use of computers contributes to the organization of the educational process in the context of the development of new information technologies. With the help of modern electronic editorial and publishing technology, students are trained in typing, scanning and processing visual material, spatial organization of text and images, get acquainted with the principles of forming text and visual information in phototypesetting machines, laser printers, risographs, slide scanners, digital cameras, etc. The Internet provides tangible assistance in organizing the editorial and publishing process, especially in obtaining information (Danilov, A.A., Danilov, A.P. and Danilova, M.G., 2016, p. 242).

The result of the development of new technological schemes for the release of printed media was that each student of the Faculty of Journalism published their own newspaper, paying particular attention to the design of the printed edition, the type of fonts and features of their psychological perception, and the modeling of the page. Students' newspapers «Pilgrim», «My newspaper», "One's own doctor», "Curious newspaper», «REDactsia», "Merry tram», «Evening Cheboksary», "The Chronicle of events», "The Revival of Russia», «Sports Chuvashia», "Sudarushka» and others (Danilov, A. A., Danilov, A. P., Danilova, M. G. and Mytnikov, A. N., 2016, p. 81).

When publishing books and magazines, students master the basic issues of organizational and creative work of the publishing house with the author, with the order of passing the material and proofreading prints. At the same time, special care is shown for the high scientific and artistic merits of the text material. Work on preparing the originals of books for release goes through all stages: working with the author, receiving the author's original, evaluating the review and approving the author's original; editorial work with the author's original accepted for publication; preparation of the publishing original for publication in foreign languages and in translation into Chuvash and Russian; the procedure for working with the author's original in terms of artistic and graphic design; proofreading of the publisher's original; the procedure for preparing the publisher's original; work with proofreads; preparation of the publisher's original for typesetting without subsequent proofreading exchange; work of the educational and publishing center with a signal copy.

Students also get acquainted with the procedure for distributing the media, with the rights to receive information, receive information requests, the rights and obligations of a journalist, responsibility for violation of legislation on the media, copyrights arising in connection with the creation and use of works of science, literature and art., with the peculiarities of advertising.

\section{CONCLUSION}

In general, the training of journalistic personnel at the Chuvash State University named after I.N. Ulyanov went through three stages: training journalists through specialization (1967-1993); five-year professional training (1994-2013); a stage of multilevel training for journalists (since 2014). The experience of many years of work in training journalistic personnel shows that they are in great demand at every stage of historical development. Further improvement of the system of education of creative workers of the editorial offices of the media, taking into account the development of market conditions and the expansion of new information technologies - is the main task of the collective of the Department of Journalism of the Chuvash State University named after I.N. Ulyanov today. 


\section{ACKNOWLEDGEMENT}

The reported study was funded by RFBR and Chuvash Republic according to the research project № 19412-210003.

\section{REFERENCE LIST}

Danilov, A.A. (2008). Historical experience of the development of television in the regions of Russia (second half of XX - early XXI centuries).

Danilov, A.A. (2006). Television in the regions of Russia: history and modernity (based on the materials of the Chuvash Republic).

Danilov, A.A., Danilov, A.P. and Danilova, M.G. (2016). Web media text in modern news journalism of Chuvashia. Ashmarin Readings.

Danilov, A.A., Danilov, A.P., Danilova, M.G. and Mytnikov, A.N. (2016). "New media" and mass media in Chuvashia: interaction strategies. Multimedia Journalism of Eurasia-2015.

Danilov, A.P. (2017). AND I. Tenyushev, veteran of the Great Patriotic War, professor of the Faculty of Journalism of the Chuvash State University: "We have something to remember." The official site of the journalism department of the Chuvash State University.

Danilov, A.P. (2011). Faculty of Journalism. Ulyanovets. 